\title{
The influence of application of different diesel fuel-RME blends on PM emissions from a diesel engine
}

\begin{abstract}
The aim of the research described in this paper was to determine the potential of RME in reducing particulate emissions from diesel engines. The tests were carried out at Emissions Testing Laboratory, Poznan University of Technology using the AMX-210/100 engine test bed. The AVL Micro Soot Sensor and Smoke Meter were used to measure PM emissions. The emission measurements were carried out over a 13-mode ESC cycle. The tests were conducted on a direct injection (common rail), turbocharged, Euro 4 compliant passenger car diesel engine. Four different diesel fuel/RME blends were tested. These blends contained respectively: 5, 20, 50 and 100\% RME.
\end{abstract}

Key words: diesel engine, exhaust emissions, biofuel, $R M E$

\section{Wpływ zastosowania mieszanin oleju napędowego i RME o różnym składzie na emisję cząstek stałych z silnika ZS}

\begin{abstract}
Celem badań opisanych w niniejszym artykule było określenie potencjału RME w zmniejszaniu emisji czastek statych z nowoczesnych silników ZS. Badania wykonano w Laboratorium Toksyczności Spalin Politechniki Poznańskiej z wykorzystaniem hamowni silnikowej AMX-210/100. Pomiarów emisji cząstek stałych dokonano z wykorzystaniem analizatorów spalin: AVL Micro Soot Sensor (pomiar stężenia PM) i AVL Smoke Meter (pomiar zadymienia i zaczernienia spalin oraz koncentracji sadzy). Pomiary odbywały się w teście ESC, na silniku ZS o wtrysku bezpośrednim, doładowanym turbosprężarka, zasilanym w systemie common rail i spetniającym normę emisji spalin Euro 4. W badaniach stosowano cztery paliwa: olej napędowy (ON) i RME (B100) oraz ich mieszaniny B20 i 50, zawierajace odpowiednio 20 i $50 \%$ RME.

Słowa kluczowe: silnik ZS, emisja spalin, biopaliwo, $R M E$
\end{abstract}

\section{Introduction}

Currently one of the most important factors stimulating the development of combustion engines and their fuels are the ecological aspects. This is caused by the international emission legislation getting more and more stringent. In the case of engine fuels their dominant source is still crude oil. We can however observe a slow but steady growth of the share of biofuels in the market (this results from the high crude oil prices and the threat of global warming). The situation is a result of an implemented policy that forces the fuel manufacturers and distributors to increase the share of biofuels in the world market on an annual basis.

The use of renewable fuels (biofuels in particular) aims at protecting Earth's natural resources, reducing carbon dioxide emission to the atmosphere and forcing lesser dependence on the fossil fuels. Besides, their use also positively influences the exhaust emissions, hence the air pollution.

Currently in the European market the most important biofuel is FAME (Fatty Acid Methyl Esters) manufactured mainly as Rapeseed Methyl Esters (RME). It is forecasted that the scale of production and consumption of this fuel will continue increasing as a result of the growing demand for diesel fuels and a leveled demand for the positive ignition engine fuels. Currently, to regular diesel oils FAME is added up to $7 \%$. Besides, its consumption in a pure form grows as well.

\section{Wprowadzenie}

Obecnie do najważniejszych czynników stymulujących rozwój jednostek napędowych pojazdów oraz paliw silnikowych należą aspekty ekologiczne. Jest to spowodowane stale zaostrzającymi się międzynarodowymi przepisami z zakresu emitowania do atmosfery substancji szkodliwych. W odniesieniu do paliw silnikowych wciąż dominującym źródłem ich pozyskiwania jest ropa naftowa. Obserwuje się jednak powolny, ale sukcesywny wzrost udziału biopaliw w rynku (wynika to m.in. $\mathrm{z}$ utrzymujących się na wysokim poziomie cen ropy naftowej oraz zagrożenia globalnym ociepleniem). Dzieje się tak głównie za sprawą prowadzonej w tym zakresie odpowiedniej polityki, która nakłada na producentów i dystrybutorów paliw obowiązek corocznego zwiększania udziału biopaliw w światowym rynku paliwowym.

Zastosowanie paliw odnawialnych (a zwłaszcza biopaliw) ma na celu przede wszystkim ochronę zasobów naturalnych Ziemi, zmniejszenie emisji dwutlenku węgla do atmosfery i uniezależnienie się od paliw kopalnych. Ponadto ich zastosowanie często wpływa także korzystnie na poziom toksyczności spalin silnikowych, a więc i na stopień zanieczyszczenia powietrza.

Aktualnie na rynku europejskim najważniejszym biopaliwem jest FAME (Fatty Acid Methyl Esters), produkowane przede wszystkim w postaci estrów metylowych kwasów tłuszczowych oleju rzepakowego RME (Rapeseed Methyl 
The use of FAME as a fuel in its pure form or an additive significantly reduces the diesel engine exhaust emission level. This most frequently results in the reduction of the emission of $\mathrm{CO}, \mathrm{HC}$ and $\mathrm{PM}$ and a growth of the emission of $\mathrm{NO}_{\mathrm{x}}$ [9]. There are many works available in the literature related to this issue $[1-8]$. We need to note however that many of these investigations related to FAME were carried out on engines of older generation (operating based on conventional injection systems). This is, among other things, a result of a dynamic development of diesel engines in recent years (new injection systems - significant increase in the injection pressures, downsizing etc.) Besides, many of the above-mentioned works relates to the measurement of the emissions in only one or a few selected engine operating points, which gives only a limited perspective on the influence of the use of FAME on the emission in the whole field of engine work. The said issues were the stimuli for the investigations discussed in this paper. The investigations consisted in measuring of the exhaust emissions from diesel engines fueled with diesel oil, RME, and the blends of the two under the homologation conditions of European Stationary Cycle (ESC).

\section{Research object and measuring equipment}

The investigations presented in this paper were carried out on a chassis dynamometer by AUTOMEX, fitted with an AMX-210/100 eddy-current brake (Fig. 1). For the tests a passenger car with a diesel engine was used representative of small powertrains of typical technological advancement of these engines (Table 1 ).

The measurements of the exhaust emissions were carried out under the conditions of a homologation test ESC (13-modes). While performing the tests the engine was fueled with a conventional diesel fuel (DF) and RME fuel in its pure form (B100) and a blend of the two: B20 (20\% RME and $80 \%$ DF) and B50 (50\% RME and 50\% DF). While composing the B20 and B50 fuels the authors took into account the

Table 1. Specifications of the tested engine

Tabela 1. Dane techniczne silnika użytego w badaniach

\begin{tabular}{|c|c|}
\hline $\begin{array}{l}\text { Engine type/ } \\
\text { rodzaj silnika }\end{array}$ & $\begin{array}{l}\text { Diesel, 4-cylinder in-line/ } \\
\text { ZS 4-cylindrowy, rzędowy }\end{array}$ \\
\hline $\begin{array}{l}\text { Displacement/ } \\
\text { objętość skokowa }\end{array}$ & $1.251 \mathrm{dm}^{3}$ \\
\hline Max. power/moc maks. & $51 \mathrm{~kW} @ 4000 \mathrm{rpm} / \mathrm{obr} / \mathrm{min}$ \\
\hline Max. torque/moment maks. & 180 Nm@1750rpm/obr/min \\
\hline $\begin{array}{l}\text { Injection/combustion type/ } \\
\text { uktad zasilania }\end{array}$ & $\begin{array}{l}\text { Direct injection, common rail, turbo- } \\
\text { charged (intercooled)/wtrysk bezpo- } \\
\text { średni, doładowanie turbosprężarka }\end{array}$ \\
\hline $\begin{array}{l}\text { Number of valves/ } \\
\text { liczba zaworów }\end{array}$ & $\begin{array}{l}4 \text { per cylinder/ } \\
4 \text { na cylinder }\end{array}$ \\
\hline $\begin{array}{l}\text { Max. injection pressure/ } \\
\text { maks. ciśnienie wtrysku }\end{array}$ & $140 \mathrm{MPa}$ \\
\hline $\begin{array}{l}\text { Fuel dose split/podziat } \\
\text { dawki paliwa }\end{array}$ & $\begin{array}{l}\text { up to } 4 \text { injections per stroke/ } \\
\text { do } 4 \text { wtrysków na cykl }\end{array}$ \\
\hline $\begin{array}{l}\text { Emission control/układy } \\
\text { oczyszczania spalin }\end{array}$ & $\begin{array}{c}\text { Oxidation catalyst/reaktor utleniajacy, } \\
\text { EGR (Exhaust Gas Recirculation) }\end{array}$ \\
\hline Calibrated to/norma emisji & Euro 4 \\
\hline
\end{tabular}

Esters). Przewiduje się, że skala produkcji i zużycia tego rodzaju paliwa będzie się nadal zwiększać, w wyniku rosnącego zapotrzebowania na paliwa do silników o zapłonie samoczynnym i stabilnego zapotrzebowania na benzyny silnikowe. Obecnie do konwencjonalnych olejów napędowych dodaje się FAME w ilości do 7\%. Ponadto szybko wzrasta również jego zużycie w czystej postaci.

Zastosowanie FAME, jako paliwa w czystej postaci lub dodatku, znacząco redukuje toksyczność spalin silnika ZS. Powoduje to najczęściej zmniejszenie emisji CO, HC i PM oraz wzrost emisji $\mathrm{NO}_{\mathrm{x}}$ [9]. W literaturze dostępnych jest wiele prac związanych z tym zagadnieniem [1 - 8]. Należy jednak zauważyć, że duża część opisanych w literaturze prac badawczych dotyczących FAME została wykonana $\mathrm{z}$ wykorzystaniem silników starszej generacji (pracujących w oparciu o konwencjonalne układy wtryskowe), co wynika $\mathrm{z}$ tego, że badania nie zawsze nadążają za dynamicznym rozwojem w ostatnich latach silników ZS (nowe systemy wtryskowe - znaczny wzrost ciśnienia wtrysku paliwa, downsizing $\mathrm{i}$ in.). Ponadto wiele $\mathrm{z}$ wyżej wspomnianych prac dotyczy pomiarów emisji tylko w jednym lub kilku punktach pracy silnika, co daje jedynie ograniczony pogląd na wpływ stosowania FAME na toksyczność jego spalin w całym polu pracy. Kwestie te w głównej mierze zadecydowały o podjęciu realizacji badań opisanych w niniejszym artykule. Badania obejmowały pomiar zawartości substancji szkodliwych w spalinach emitowanych przez nowoczesny samochodowy silnik ZS, zasilany porównawczo konwencjonalnym olejem napędowym, RME oraz mieszaninami obu tych paliw w warunkach homologacyjnego testu ESC (European Stationary Cycle).

\section{Obiekt badań i stosowana aparatura pomiarowa}

Przedstawione w niniejszym artykule badania były realizowane na hamowni silnikowej firmy AUTOMEX, wyposażonej w hamulec elektrowirowy typu AMX-210/100 (rys. 1). Do badań wykorzystano samochodowy silnik o zapłonie samoczynnym, należący do grona małych jednostek napędowych i reprezentujący aktualny stan zaawansowania technologicznego tego typu jednostek (tab. 1).

Pomiary emisji substancji szkodliwych w spalinach odbywały się w warun-

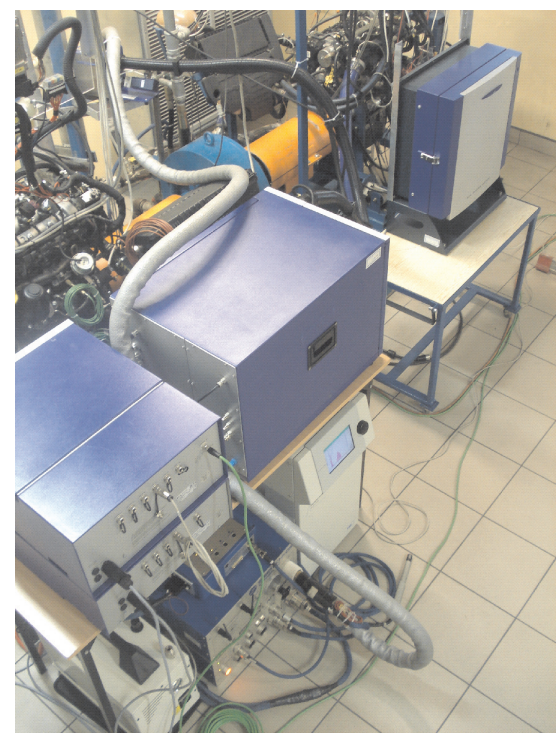

Fig. 1. Test stand - engine brake and the measurement devices silnikowa wraz z aparatura pomiarowa
Rys. 1. Stanowisko badawcze-hamownia 
Table 2. Diesel fuel (DF) and RME specifications

Tabela 2. Właściwości oleju napędowego (ON) i RME

\begin{tabular}{|c|c|c|c|c|}
\hline \multicolumn{2}{|c|}{-} & Unit & $\begin{array}{l}\mathrm{DF} / \\
O N\end{array}$ & $\begin{array}{l}\text { RME } \\
(\mathrm{B} 100)\end{array}$ \\
\hline \multicolumn{2}{|c|}{ Cetane number/liczba cetanowa } & - & 52.6 & 51.0 \\
\hline \multicolumn{2}{|c|}{ Cetane index/indeks cetanowy } & - & 52.8 & - \\
\hline \multicolumn{2}{|c|}{ Density@15들estość w temp. } & $\mathrm{kg} / \mathrm{m}^{3}$ & 833.5 & 883.0 \\
\hline \multicolumn{2}{|c|}{ Viscosity@40C/lepkośćw temp. } & $\mathrm{mm}^{2} / \mathrm{s}$ & 2.66 & 4.46 \\
\hline \multicolumn{2}{|c|}{ Sulfur content/zawartość siarki } & ppm & 9.9 & 0.8 \\
\hline \multicolumn{2}{|c|}{$\begin{array}{l}\text { Fatty acid methyl esters content/ } \\
\text { zawartość FAME }\end{array}$} & $\%(\mathrm{v} / \mathrm{v})$ & 4.9 & 98.5 \\
\hline \multicolumn{2}{|c|}{$\begin{array}{l}\text { Polyaromatic hydrocarbons } \\
\text { content/zawartość } W W A\end{array}$} & $\%(\mathrm{~m} / \mathrm{m})$ & 2.5 & - \\
\hline \multicolumn{2}{|c|}{ Iodine number/liczba jodowa } & $\mathrm{g} \mathrm{I} / 100 \mathrm{~g}$ & - & 115 \\
\hline \multirow{3}{*}{$\begin{array}{l}\text { Distillation/ } \\
\text { przebieg } \\
\text { destylacji }\end{array}$} & E250 & $\%(\mathrm{v} / \mathrm{v})$ & 39.0 & - \\
\hline & E350 & $\%(\mathrm{v} / \mathrm{v})$ & 94.5 & - \\
\hline & T95 & ${ }^{\circ} \mathrm{C}$ & 350.6 & - \\
\hline
\end{tabular}

fact that conventional fuel contained 4.9\% FAME (Table 2).

a)

The exhaust uptake for analysis was done upstream the catalytic converter. For the measurement of the mass of PM Micro Soot Sensor by AVL was used (Fig. 2b) that measures the concentration of PM in $\mathrm{mg} / \mathrm{m}^{3}$, with the use of the PASS method - Photo Acoustic Soot Sensor. The analyzer is fitted with an exhaust gas conditioner (temperature and air dilution). Besides, for the measurement of the exhaust smoke level FSN (Filter Smoke Number), soot concentration $\mathrm{C}$ and exhaust opacity $\mathrm{N}$ a Smoke Meter by AVL was used (Fig. 2a). This enables a continuous measurement of the opacity level at the same time calculating the other parameters.

\section{The results and discussion}

Using the Micro Soot Sensor analyzer by AVL the concentration of PM in each mode of the ESC homologation test was measured (Fig. 3). Then, having these measurement results appropriate calculations were made in order to determine the hourly PM emission expressed in $\mathrm{g} / \mathrm{h}$ (Fig. 4a). Beside the hourly emission (for the individual modes of the ESC test) the authors also calculated the unit emission of PM for the whole test expressed in $\mathrm{g} / \mathrm{kWh}$ (Fig. 4b).

The analysis of the emission of PM in the individual phases of the ESC test leads to a conclusion that the addition of FAME to regular diesel oil has a significant influence on the reduction of PM in the exhaust gas. As the percentage share of the RME in the fuel grows the emission of PM gets significantly reduced. This is particularly the case for the high values of the engine main parameters (engine speed and engine load). kach homologacyjnego (13-fazowego) testu ESC. Podczas wykonywania badań silnik zasilany był konwencjonalnym olejem napędowym (ON) i paliwem RME w czystej postaci (B100) oraz mieszaninami tych paliw: B20 (20\% RME i 80\% ON) oraz B50 (50\% RME i 50\% ON). Przy komponowaniu paliw B20 i B50 uwzględniono, że konwencjonalny olej napędowy zawierał 4,9\% FAME (tab. 2).

Pobór spalin do analizy odbywał się przed reaktorem katalitycznym. Do pomiaru masy cząstek stałych użyto analizatora Micro Soot Sensor firmy AVL (rys. 2b), który mierzy stężenie PM w $\mathrm{mg} / \mathrm{m}^{3}$, z wykorzystaniem metody fotoakustycznej (PASS - Photo Acoustic Soot Sensor). Analizator ten jest wyposażony w układ przygotowania spalin (zarówno pod względem temperaturowym, jak i rozcieńczenia powietrzem). Ponadto do pomiarów zadymienia spalin FSN (Filter Smoke Number) oraz zaczernienia spalin $\mathrm{N}$ wykorzystano analizator Smoke Meter firmy AVL (rys. 2a). Umożliwia on ciągły pomiar zaczernienia spalin i jednocześnie oblicza pozostałe parametry.

b)

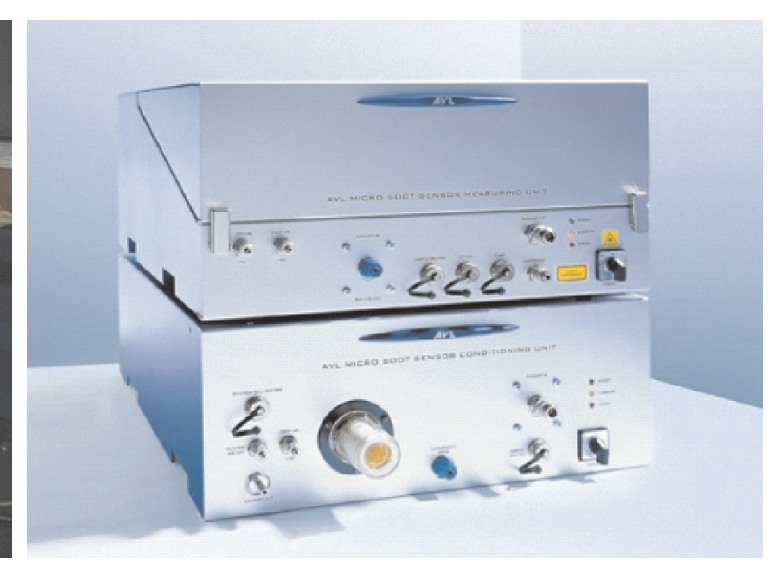

Fig. 2. The devices for the measurement of the PM content in the exhaust gas [11]: a) AVL Smoke Meter, b) AVL Micro Soot Sensor Meter, b) AVL Micro Soot Sensor

\section{Wyniki badań i ich analiza}

Przy wykorzystaniu analizatora Micro Soot Sensor firmy AVL zmierzono stężenie cząstek stałych w każdej fazie homologacyjnego europejskiego testu stacjonarnego (rys. 3). Następnie, dysponując tymi pomiarami, dokonano stosownych obliczeń w celu określenia godzinowej emisji PM, wyrażonej w g/h (rys. 4a). Oprócz godzinowej emisji (dla poszczególnych faz testu ESC) obliczono też jednostkową emisję cząstek stałych dla całego testu, wyrażoną w g/kWh (rys. 4b).

Analiza emisji cząstek stałych w poszczególnych fazach testu ESC pozwala stwierdzić, że dodatek estrów metylowych kwasów tłuszczowych oleju rzepakowego RME do konwencjonalnego oleju napędowego ma znaczący wpływ na zmniejszenie zawartości PM w emitowanych przez silnik spalinach. Wraz ze wzrostem udziału procentowego RME w paliwie, emisja cząstek stałych ulega wyraźnej redukcji. 


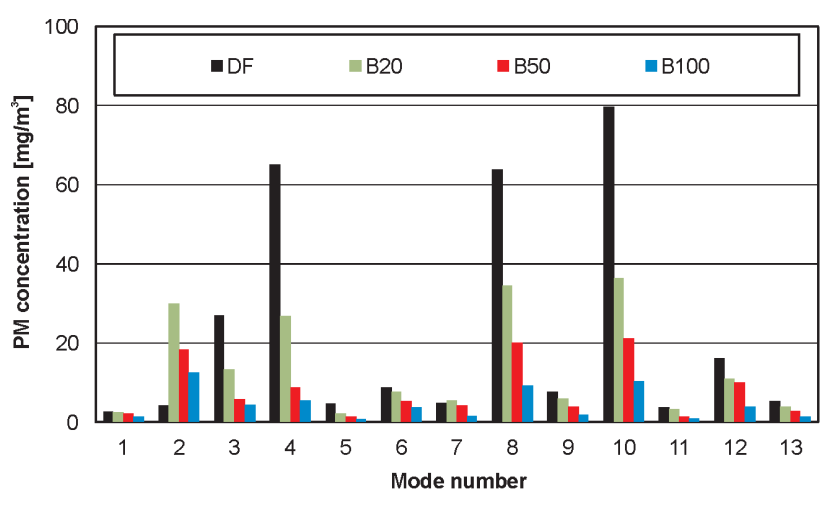

Fig. 3. The concentration of PM in the individual phases of the ESC test Rys. 3. Stężenie cząstek stałych w poszczególnych fazach testu ESC
Jest to szczególnie widoczne przy dużych wartościach głównych parametrów pracy silnika (prędkości obrotowej i obciążenia).

Czyste paliwo RME (B100) charakteryzuje się bardzo małą emisją cząstek stałych. Dla wszystkich faz testu nie przekracza ona $1,5 \mathrm{~g} / \mathrm{h}$. Szczególnie interesujące jest zestawienie i porównanie emisji PM dla czystego oleju napędowego oraz paliwa B100. W niektórych przypadkach (dla faz testu charakteryzujących się dużą prędkością obrotową oraz maksymalnym obciążeniem) uzyskano różnice w emisji godzinowej rzędu nawet $88 \%$. Natomiast emisja jednostkowa (obliczona dla całego testu ESC) jest o około $83 \%$ mniejsza przy zastosowaniu paliwa B100. Wartości te są korzystniejsze niż podane przez EPA (Environmental Protection Agency - Urząd Ochrony Środowiska w USA),

Pure RME (B100) is characterized by a very low emission of PM. It does not exceed the value of $1.5 \mathrm{~g} / \mathrm{h}$ in any phase of the test. Particularly interesting is the comparison of the emissions of PM for pure diesel oil and pure RME B100. In some cases (for the test phases characterized by high engine speed and maximum load) the authors obtained differences in the hourly emission of up to $88 \%$. The unit emission however (calculated for the whole ESC test) is approximately $83 \%$ lower if the B100 fuel is used. These values are more advantageous than those given

a)

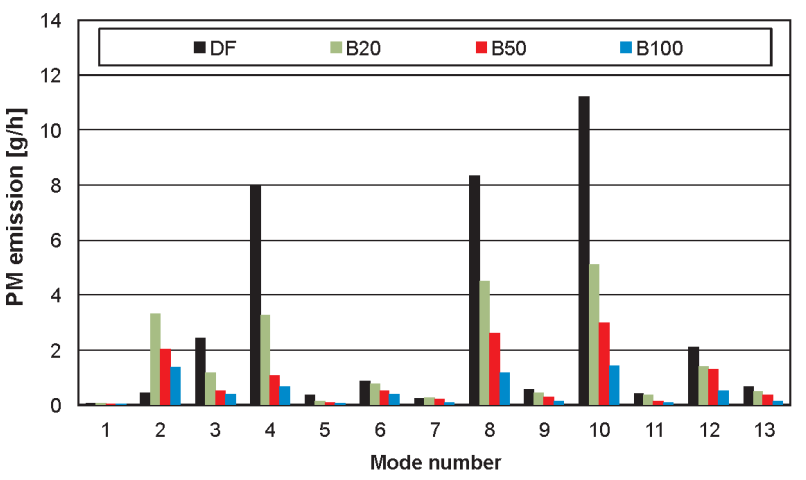

b)

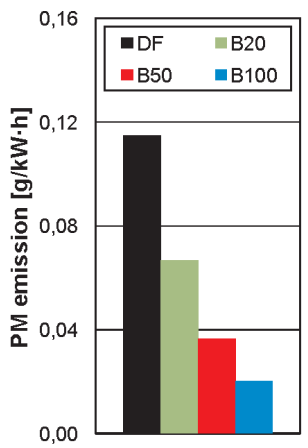

Fig. 4. The emission of PM: a) in the individual phases of the ESC test, b) in the whole ESC test Rys. 4. Emisja PM: a) w poszczególnych fazach testu ESC, b) w catym teście ESC

by EPA (Environmental Protection Agency) where an approximately 5\% reduction of PM emission is assumed for pure FAME [10].

The proof of the significant $\mathrm{PM}$ emission reduction when using fuels containing FAME are the results of the smoke level and opacity measurements (Fig. 5 and 6).

\section{Conclusions}

Fueling of a diesel engine with fuels containing RME brings measurable results such as a reduced emission of PM. As a result of the performed measurements the authors

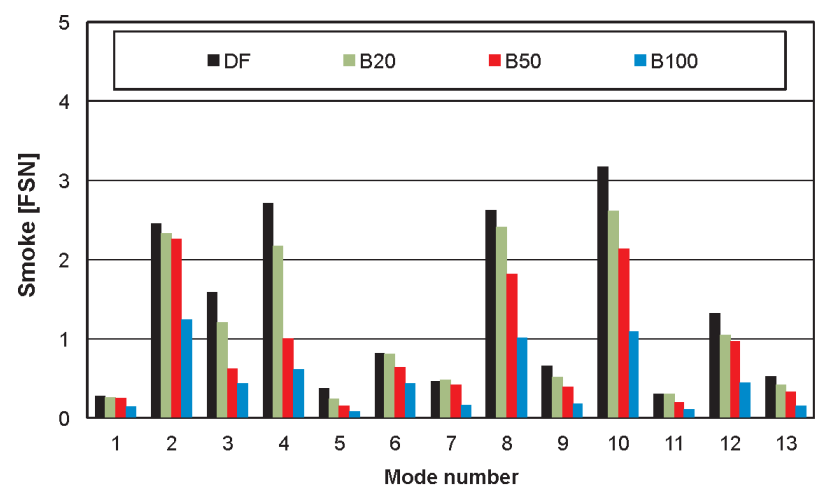

Fig. 5. Smoke level in the individual ESC test phases Rys. 5. Zadymienie spalin w poszczególnych fazach testu ESC gdzie zakłada się około 50-procentową redukcję emisji cząstek stałych dla czystego FAME [10].

Potwierdzeniem znacznej redukcji emisji cząstek stałych przy zastosowaniu paliw zawierających w swoim składzie chemicznym estry metylowe kwasów tłuszczowych oleju rzepakowego RME są także wyniki pomiarów zadymienia oraz zaczernienia spalin (rys. 5 i 6 ).

\section{Podsumowanie}

Zasilanie silnika spalinowego o zapłonie samoczynnym paliwami zawierającymi RME przynosi wymierne korzyści w postaci zmniejszonej emisji cząstek stałych. W wyniku przeprowadzonych pomiarów zaobserwowano wyraźny spadek wartości emisji godzinowej w każdej fazie testu ESC oraz emisji jednostkowej obliczonej dla całego testu. Taki wpływ RME na zawartość cząstek stałych w spalinach jest także opisywany w wielu publikowanych pracach badawczych.

Analizując wpływ na emisję PM paliw o różnej zawartości RME, można zauważyć, że zmniejszenie tej emisji jest proporcjonalne do zawartości RME, a zatem najwyższe dla paliwa B100 - dla czystego RME odnotowano prawie sześciokrotnie niższy poziom emisji PM niż dla konwencjonalnego oleju napędowego.

Wykonane badania wykazały zatem istotny korzystny wpływ RME (jako składnika paliwa) na emisję cząstek sta- 
observed a significant drop in the hourly emission of PM in each mode of the ESC test as well as unit emission calculated for the whole test. Such an influence of RME on the PM content in the exhaust gases is also described in many published research works.

Analyzing the influence of fuels of different RME content on the PM emission we can observe that the reduction of this emission is proportional to the RME content, thus, it reaches the maximum value for B100 - for pure RME an almost 6 times lower PM emission was recorded as compared to regular diesel oil.

The investigations carried out have shown a significant positive influence of RME (as a fuel component) on the emission of PM from a modern turbocharged diesel engine fitted with a common rail fuel system. Following the performed PM emission investigations the authors conclude that the most advantageous is the use of RME in its pure form (B100).

Paper reviewed/Artykut recenzowany

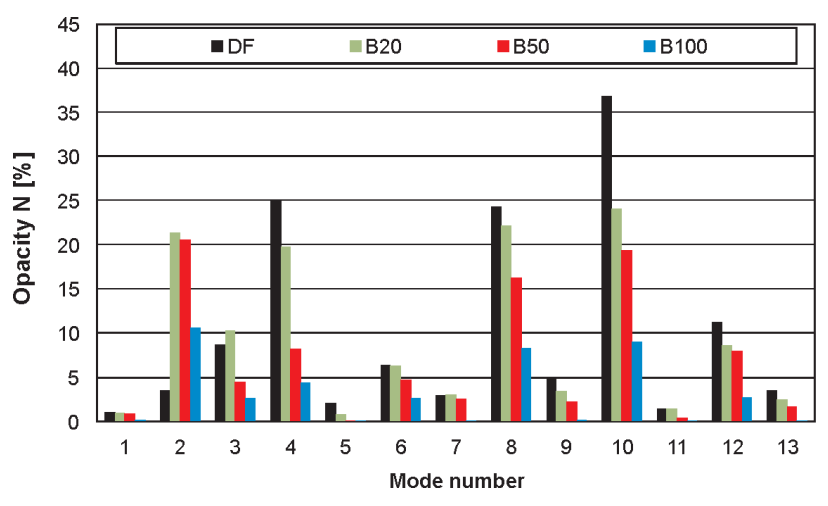

Fig. 6. Exhaust gas opacity in the individual ESC test phases Rys. 6. Zaczernienie spalin w poszczególnych fazach testu ESC

łych przez nowoczesny, turbodoładowany silnik ZS, zasilany w systemie common rail. W świetle wykonanych badań, w zakresie emisji PM najkorzystniejsze jest stosowanie RME w czystej postaci (B100).

\section{Bibliography/Literatura}

[1] Daisuke Kawano, Hajime Ishii and Yuichi Goto: Effect of Biodiesel Blending on Emission Characteristics of Modern Diesel Engine. SAE Paper 2008-01-2384.

[2] Durbin T.D., Cocker III D.R., Sawant A.A., Johnson K., Miller J.W., Holden B.B., Helgeson N.L. and Jack J.A.: Regulated Emissions from Biodiesel Fuels from On/Off-Road Applications. Atmospheric Environment no 41 (2007).

[3] Fontaras G., Karavalakis G., Kousoulidou M., Tzamkiozis T., Ntziachristos L., Bakeas E., Stournas S., Samaras Z.: Effects of Biodiesel on Passenger Car Fuel Consumption, Regulated and Non-Regulated Pollutant Emissions over Legislated and Real-World Driving Cycles. Fuel no 88 (2009).

[4] Fujia Wu, Jianxin Wang, Wenmiao Chen and Shijin Shuai: A Study on Emission Performance of a Diesel Engine Fueled with Five Typical Methyl Ester Biodiesels. Atmospheric Environment no 43 (2009)

[5] Graboski M.S., McCormick R.L.: Combustion of Fat and Vegetable Oil Derived Fuels in Diesel Engines. Prog. Energy Combust. Sci. Vol. 24 (1998).

Prof. Jerzy Merkisz, DSc., DEng. - Professor in the Faculty of Working Machines and Transportation at Poznan University of Technology.

Prof. Jerzy Merkisz - profesor na Wydziale Maszyn Roboczych i Transportu Politechniki Poznańskiej.

e-mail:jerzy.merkisz@put.poznan.pl

Miłosław Kozak, DEng. - doctor in the Faculty of Working Machines and Transportation at Poznan University of Technology.

Dr inż. Miłoslaw Kozak - adiunkt na Wydziale Maszyn Roboczych i Transportu Politechniki Poznańskiej.

e-mail: miloslaw.kozak@put.poznan.pl
[6] Lei Zhu, Wugao Zhang, Wei Liu and Zhen Huang: Experimental Study on Particulate and NOx Emissions of a Diesel Engine Fueled with Ultra Low Sulfur Diesel, RME-Diesel Blends and PME-Diesel Blends. Science of the Total Environment no 408 (2010).

[7] Nigro F., Trielli M., Costa C.: Emission Characteristics of a Diesel Engine Operating with Biodiesel and Blends. SAE Paper 2007-01-2635.

[8] Szlachta Z.: Zasilanie silników wysokoprężnych paliwami rzepakowymi. WKŁ, Warszawa 2002.

[9] Lauperta M., Armas O. and Rodriguez-Fernandez J.: Effect of Biodiesel Fuels on Diesel Engine Emissions. Progress in Energy and Combustion Science no 34 (2008).

[10] Assessment and Standards Division (Office of Transportation and Air Quality of the US Environmental Protection Agency). A Comprehensive Analysis of Biodiesel Impacts on Exhaust Emissions. EPA420-P-02-001 (2002).

[11] www.avl.com

Jacek Pielecha, DEng. - doctor in the Faculty of Working Machines and Transportation at Poznan University of Technology.

Dr inż. Jacek Pielecha - adiunkt na Wydziale Maszyn Roboczych i Transportu Politechniki Poznańskiej.

e-mail: jacek.pielecha@put.poznan.pl

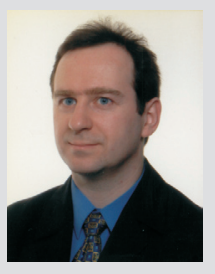

Maciej Andrzejewski, MSc, Eng. - PhD student at the Faculty of Working Machines and Transportation at Poznan University of Technology.

Mgr inż. Maciej Andrzejewski - doktorant na Wydziale Maszyn Roboczych i Transportu Politechniki Poznańskiej.

e-mail: maciej.andrzejewski@doctorate.put.poznan.pl

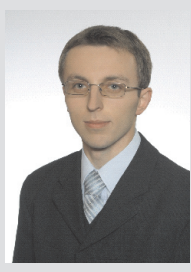

